\title{
Analisis Kelayakkan Bisnis, Strategi Pemasaran dan Modal Reliji pada Usaha Waroeng Spesial Sambal Yogyakarta
}

\author{
Mufti Afif dan Isna Arifa ${ }^{1}$ \\ UNIDA Gontor, Kampus 3 Univ. Darussalam Gontor Putri 1 Mantingan, Ngawi, Jawa Timur \\ Email: alamjagatraya12@gmail.com
}

\begin{abstract}
The process of business feasibility analysis is certainly closely related to the management of a business, which will analyze the prospects of market share, future prospects of the product especially to the appropriate marketing strategies to achieve the goals of a business. Waroeng SS is one of the culinary business unit known by the people in Yogyakarta area. This culinary business unit offers products that are different from other food stalls, sambal with various variants but still embed the characteristic of Javanese tongue. And now has earned billions of rupiah in turns per month, and outlets have reached 80 branches in the Java-Bali region. Therefore this paper should like to examine the business feasibility of SS owner in their begining and also to know about their product marketing strategy recently.

The type of research in this work uses a qualitative approach by digging data through direct interviews, both to the management of Waroeng SS and some of its customers.

The results conclude that business feasibility analysis is well planned; from the process of market determination, market segmentation, location, price and product have all been analyzed. While the marketing strategy which is done just make the customers trusty as their priority then they will certainly share the information to their colleagues. And the most important things according to the owner are trust in Allah SWT and shadaqah as their priority.
\end{abstract}

Keywords: Business Feasibility, Strategy, Marketing, Waroeng SS

\begin{abstract}
Abstrak
Pembahasan studi kelayakan bisnis sangat penting bagi calon pengusaha untuk merancang pelaksanaan usahanya. Proses analisa kelayakan bisnis tentunya sangat terkait dengan manajemen pengelolaan suatu usaha, dimana akan dianalisa prospek pangsa pasar, prospek masa depan produk hingga strategi-strategi pemasaran yang tepat untuk mencapai tujuan suatu usaha. Waroeng SS adalah salah satu unit usaha kuliner yang dikenal oleh masyarakat Jawa Tengah khususnya wilayah Yogyakarta. Unit usaha kuliner ini menawarkan produk yang beda dengan warung-warung makan lain, yaitu sambal dengan berbagai varian namun masih melekatkan ciri khas lidah orang jawa. Suatu usaha sukses yang didirikan tahun 2002 oleh seorang mahasiswa Teknik Universitas Gadjah Mada kini telah meraup omset milyaran rupiah tiap bulannya, serta outletnya sudah mencapai 80 cabang di wilayah Jawa-Bali. Oleh sebab itulah karya ilmiah ini hendak mengkaji studi kelayakan bisnis yang dilakukan oleh pendiri Waroeng SS di awal perintisan usaha serta mengetahui strategi pemasaran produk kulinernya selama ini.

Jenis penelitian pada karya ini menggunakan pendekatan kualitatif dengan menggali data melalui wawancara langsung, baik kepada pihak manajemen Waroeng SS dan beberapa konsumennya. Hasil penelitian menyimpulkan bahwa analisa kelayakan bisnis sangat terencana; dari proses penentuan pasar, segmentasi pasar, lokasi, harga dan produk semua telah dianalisa. Sedangkan strategi pemasaran yang dilakukan hanya mengedepankan kepercayaan pelanggan, yang tentunya akan menyebarkan informasi ke rekan-rekan sejawatnya. Waroeng SS tidak pernah iklan melalui media publikasi apapun. Dan yang paling penting menurut owner adalah budaya sedekah dan tawakkal ke pada Allah SWT terkait masalah rezeki.
\end{abstract}

Kata Kunci: Kelayakan Bisnis, Strategi, Pemasaran, Waroeng SS

${ }^{1}$ Nomor HP: (085335103343 atau 081939000811$)$ 


\section{PENDAHULUAN}

Pembahasan mengenai studi kelayakan bisnis tidak akan terlepas dari isu skill manajerial dan beberapa aspek yang terkait dengan aspek demografi, ekonomi, teknologi, politik-hukum dan sosial-budaya. Di amana semua aspek ini saling memiliki keterkaitan satu sama lain untuk mendukung kelayakan suatu bisnis baik dilihat dari segi mikro maupun makro.

Aspek-aspek di bidang manajemen merupakan bagian yang penting sehingga mampu memberikan dampak berupa keputusan bisnis, serta menghasilkan kajian yang bersifat menyeluruh dan mencoba menyoroti segala aspek kelayakan proyek bahkan masalah peluang investasi, inilah yang sering kali disebut proses studi kelayakan bisnis. Dengan kata lain, studi kelayakan bisnis merupakan gambaran kegiatan usaha yang direncanakan sesuai dengan kondisi, potensi, serta peluang yang tersedia dari berbagai aspek (Ibrahim, 2003).

Kecerdasan spiritual memungkinkan seseorang untuk berpikir lebih kreatif, berwawasan jauh, membuat atau bahkan mengubah aturan, yang membuat orang tersebut dapat bekerja lebih baik (Idrus, 2002). Lisda Rahmasari (2012) menyatakan bahwa kecerdasan spiritual mampu menjadikan manusia sebagai mahluk yang lengkap secara intelektual, emosional dan spiritual. Roni Mohammad dan Mustofa (2014) meneliti pengaruh tingkat pemahaman agama (spiritual) terhadap perilaku dagang dengan pendekatan kuatitatif menghasilkan bahwa tingkat pemahaman agama yang terdiri dari Iman, Islam dan Ihsan pedagang pasar minggu berpengaruh signifikan terhadap prilaku dagang/bisnis.

Warung Spesial Sambal atau yang disingkat dengan "SS" diinisiasi oleh bapak Yoyok Hery Wahyono (kelahiran Boyolali, 02 September 1973) pada tahun 2002. Kala itu beliau merupakan mahasiswa Fakultas Teknik UGM kota Yogyakarta, atas dasar hobi memasak menu sambal beliau memutuskan untuk memulai usaha dan siap mengembangkan usahanya tersbut. Awalnya hanya usaha kuliner beliau hanya berwujud kaki lima, yaitu tepatnya di Jln. Kaliurang sebelah barat Grha Sabha Pramana UGM pada Agustus
2002, dengan jadwal jam buka setiap jam 17.00 sampai jam 22.00.

Sampai saat ini waroeng "SS" sudah memiliki 80 cabang. Sistem pembukaan cabang ada 2 jenis; yaitu kemitraan \& franchise. Kemitraan Usaha adalah jalinan kerjasama usaha yang saling menguntungkan antara pengusaha kecil dengan pengusaha menengah/besar (Perusahaan Mitra) disertai dengan pembinaan dan pengembangan oleh pengusaha besar, sehingga saling memerlukan, menguntungkan dan memperkuat. Kemitraan usaha akan menghasilkan efisiensi dan sinergi sumber daya yang dimiliki oleh pihak-pihak yang bermitra dan karenanya menguntungkan semua pihak yang bermitra.

Belajar dari kesuksesan Waroeng "SS" ini, penulis hendak mengkaji asas motivasi serta perencanaan bisnis yang terkait dengan daya analisis atau studi kelayakan usaha yang dilakukan oleh owner Waroeng SS, yaitu bapak Yoyok Hery Wahyono. Disamping itu menggali strategi pemasaran yang dilakukan pihak manajemen sehingga dapat dicapai tujuan yang diinginkan.

\section{TINJAUAN PUSTAKA}

Penelitian oleh Muh. Supriyanto dan Rino Desanto W. menunjukkan bahwa studi kelayakan usaha sangat dipandang perlu bagi calon pengusaha atau pelaku proyek dengan maksud kajian untuk meninjau kembali ketepatan layak atau tidaknya suatu usaha dilaksanakan, karena tidak sedikit bedan usaha yang mendirikan sebuah usaha dengan biaya atau modal yang cukup besar namun tidak memberikan hasil keuntungan yang signifikan, strategi pengembangan usaha dalam penelitian menggunakan analisis SWOT dengan tujuan agar usaha tersebut mampu berkembang dengan baik (Desanto, 2011).

Menilai kelayakan usaha harus dilihat dari aspek pasar dan pemasaran, aspek teknis dan aspek finansial yang sesuai dengan kondisi usaha yang hendak dijalankan. Adapun strategi pemasaran yang digunakan oleh penulis adalah; 1) diversifikasi produk, 2) berpartisipasi pada suatu even (Purnamasari dan hendrawan, 2008). 
Nunung Nurhayati, Musa Hubeis dan Sapta Raharja menyimpulkan dalam hasil penelitiannya bahwa analisis kelayakaan usaha dilakukan dengan analisis kelayakan finansial yang meliputi NPV, IRR, Net B/C dan PBP. Analisis ini dilakukan dengan mengetahui komponen biaya pengeluaran dan pendapatan selama satu tahun. Adapun Strategi pemasaran yang dilakukan adalah secara langsung produk didistribusikan oleh pedagang keliling dengan menggunakan sepeda motor ke sekitar wilayah Kuningan dan Cirebon. Sistem pemasaran ini dinilai sangat efektif untuk memperluas jaringan pemasaran, konsumen dapat memilih dan membeli produk tahu melalui pedagang keliling, hingga mampu membeli ke kios penjualan langsung (Nurhayati dkk, 2009).

\section{Pengertian Studi Kelayakan Bisnis}

Studi kelayakan bisnis merupakan suatu kegiatan yang mempelajari secara mendalam kondisi bisnis yang akan dijalankan dalam rangka ataupun bertujuan untuk menentukan layak atau tidaknya usaha tersebut (Rusdiana, 2014). Studi kelayakan bisnis atau juga bisa disebut dengan analisis proyek bisnis, ialah penelitian tentang layak atau tidaknya suatu bisnis dilaksanakan dengan menguntungkan secara terus menerus. Studi ini pada dasarnya membahas berbagai konsep dasar yang berkaitan dengan keputusan dan proses pemilihan proyek bisnis agar mampu memberikan manfaat ekonomis dan sosial sepanjang waktu. Dalam studi ini pertimbangan ekonomis dan teknis sangat penting karena akan dijadikan dasar implementasi kegiatan usaha (Suryana, 2006).

Studi kelayakan bisnis juga merupakan penelitian terhadap rencana bisnis yang tidak hanya menganalisa layak atau tidaknya bisnis dibangun, tetapi juga saat dioperasionalkan secara rutin dalam rangka pencapaian keuntungan yang maksimal untuk waktu yang tidakk ditentukan misalnya rencana peluncuran produk baru (Umar, 2007). Mengingat kondisi di masa mendatang penuh ketidakpastian, maka studi yang dilakukan tentunya meliputi berbagai aspek seperti aspek hukum, aspek sosial-ekonomi dan budaya, aspek pasar dan pemasaran, aspek teknis dan teknologi, aspek manajemen dan aspek keuangan (Umar, 2007).

\section{Tujuan Studi Kelayakan Bisnis}

Ketika seorang calon pengusaha ingin mengetahui kelayakan usahanya tersebut, tentunya ia harus mengetahui tujuannya yang hendak dicapai. Dalam hal ini Kasmir Jakfar menyebutkan bahwa sedikitnya ada lima tujuan untuk suatu usaha/proyek dilakukan studi kelayakannya, yaitu (Kasmir, dkk, 2007);

\section{Minimalisir resiko kerugian.}

Untuk mengatasi resiko kerugian pada masa yang akan datang harus ada semacam kondisi kepastian. Fungsi studi kelayakan ini untuk memetakan resiko yang dapat dikendalikan maupun yang tidak dapat dikendalikan.

\section{Memudahkan perencanaan.}

Setelah tahap peramalan terjadi maka dapat dilakukan perencanaan dan hal-hal yang perlu direncanakan, terkait dengan jenis, dan pelaksanaan pekerjaan.

\section{Memudahkan pelakasanaan pekerjaan.}

Berbagai rencana yang sudah disusun akan memudahkan pelaksanaan usaha. Pedoman yang telah tersusun secara sistematis, menyebabkan usaha yang telah direncanakan dapat tepat sasaran dan sesuai dengan rencana yang sudah disusun.

\section{Memudahkan pengawasan.}

Pelaksanaan bisnis yang sesuai dengan rencana yang telah disusun, akan mempermudah bagi pelaku usaha untuk melakukan pengawasan terhadap jalannya usaha. Pengawasan ini perlu dilakukan agar tidak melenceng dari rencana yang telah disusun.

\section{Memudahkan pengendalian.}

Tujuan aspek pengendalian ini ialah mengendaliakan agar tidak melenceng dari rel yang sesungguhnya, sehingga tujuan perusahaan akan tercapai.

\section{Analisis Kelayakan Usaha}

Analisis kelayakan Usaha melipu hal-hal berikut: 


\section{Aspek Pemasaran}

Menurut Irawan, Pemasaran adalah proses sosial dimana individu dan kelompok mendapat apa yang mereka butuhkan dan inginkan dengan menciptakan dan mempertukarkan produk dan nilai dengan individu atau kelompok lainnya (Irawan, dkk, 1998).

Strategi pemasaran sebagai alat fundamental yang direncanakan untuk mencapai tujuan perusahaan dengan mengembangkan keunggulan bersaing yang berkesinambungan melalui pasaryang dimasuki dan program pemasaran yang digunakan untuk melayani pasar sasaran tersebut (Tjiptono, dkk, 2012). Dengan kombinasi dari strategi produk, harga, promosi, dan tempat/ distribusi dalam mencapai tujuan pemasaran dinamakan "marketing mix" atau bauran pemasaran. Marketing mix juga sering disebut 4P (Product, Price, Promotion, and Placement). Dalam pemasaran yang merupakan alat yang digunakan produsen untuk mempengaruhi konsumen (Nurhayati, dkk, 2009).

\section{Produk (Product)}

Suatu yang dapat ditawarkan ke pasar untuk mendapatkan perhatian, agar produk yang dijual mau dibeli, digunakan atau dikonsumsi yang dapat memenuhi suatu keinginan atau kebutuhan dari konsumen

\section{Harga (Price)}

Sejumlah nilai yang ditukarkan konsumen dengan manfaat dari memiliki atau menggunakan produk atau jasa yang nilainya ditetapkan oleh pembeli dan penjual melalui tawar menawar, atau ditetapkan oleh penjual untuk satu harga yang sama terhadap semua pembeli.

\section{Tempat (Place)}

Tempat diasosiasikan sebagai saluran distribusi yang ditujukan untuk mencapai target konsumen.

\section{Promosi (Promotion)}

Sebagai salah satu cara pemasaran untuk mengkomunikasikan dan menjual suatu produk kepada konsumen yang berpotensi.

Dalam kaitannya dengan studi kelayakan suatu usaha, aspek pasar dan pemasaran merupakan salah satu aspek yang paling penting. Hal ini disebabkan karena aspek pasar dan pemasaran sangat menentukan hidup matinya suatu perusahaan. Jika aspek tersebut tidak dilakukan secara teliti, maka tidak menutup kemungkinan perusahaan tersebut akan terancam (Kasmir, dkk, 2007). Adapun tujuan perusahaan dalam pemasaran yaitu: untuk meningkatkan penjualan dan laba, untuk menguasai pasar, untuk mengurangi saingan, untuk menaikkan prestise produk tertentu di pasaran, untuk memenuhi pihakpihak tertentu (Kasmir dkk, 2007).

Aspek Industri

Kekuatan Supplier, Pemasok atau supplier merupakan perusahaan yang menyediakan bahan baku bagi perusahaan lain. Sehingga pemasok memegang peranan penting bagi kelancaran bisnis.

Persaingan Usaha, Persaingan merupakan suatu bentuk usaha yang dilaksanakan supaya mendapatkan kemenangan atau mendapatkan posisi yang lebih baik tanpa harus terjadi benturan fisik atau konflik. Persaingan mempunyai kekuatan yang cukup besar untuk mempengaruhi pasar, sehingga perusahaan perlu mengetahui situai pesaingnya (Teknik, 2013).

\section{Aspek Produksi atau Operasional}

Penilaian kelayakan teknis atau operasi perusahaan dijalankan. Penentuan kelayakan bisnis atau operasi perusahaan menyangkut hal-hal yang berkaitan dengan produksi atau operasi, sehingga apabila tidak dianalisis dengan baik, maka akan berakibat fatal bagi perusahaan dalam perjalanannya di kemudian hari.

Hal-hal yang perlu diperhatikan dalam aspek ini adalah masalah penentuan lokasi, luas produksi, tata letak (layout), penyusunan peralatan pabrik, dan proses produksinya termasuk pemilihan teknologi. Jadi, analisis dari aspek operasi adalah untuk menilai kesiapan perusahaan dalam menjalankan usahanya (Kasmir, dkk, 2007). Ada tiga masalah pokok yang dihadapi perusahaan yaitu masalah penentuan posisi perusahaan, masalah desain dan masalah operasional (Jurnal Akuntansi, 2013). 
Analisis Aspek Keuangan

Investasi yang dilakukan dalam berbagai bidang usaha tentu memerlukan sejumlah modal disamping keahlian lainnya. Modal yang digunakan untuk membiayai suatu bisnis, mulai dari biaya prainvestasi, biaya investasi dalam aktiva tetap, hingga modal kerja.

Untuk pertama kalinya, modal digunakan untuk membiayai biaya prainvestasi seperti pengurusan izin-izin dan pembuatan studi usaha. Kemudian selanjutnya yang harus dikeluarkan adalah untuk pembelian aktiva tetap seperti pembelian tanah, pendirian bangunan atau gedung, pembelian mesin-mesin, dan aktiva tetap lainnya. Modal juga digunakan untuk biaya operasional pada saat bisnis tersebut dijalankan, misalnya untuk pembelian bahan baku, gaji, dan biaya operasi lainnya.

Besarnya modal untuk investasi yang diperlukan tergantung dari jenis usaha yang akan dijalankan. Untuk memenuhi kebutuhan investasi tersebut, modal dapat dicari dari berbagai sumber dana yang ada. Dapat menggunakan modal sendiri atau modal asing. Hal ini dilihat darisegi biaya, waktu, persyaratan untuk memperolehnya, dan jumlah yang dapat dipenuhi (Kasmir, dkk, 2007).

Meskipun pelaku usaha memiliki peluang untuk menginventasiakan dananya untuk mengembangkan produk baru, meremajakan armada kendaraan (truk, bus, kapal) atau mesin-mesin untuk garmen, memperluas daerah pemasaran untik produksi baru, membangun gedung baru dan lain sebagainya (Sudaryono, 2015).

\section{Aspek Sumber Daya Manusia}

Dalam setiap pelaksanaan ide usaha, pasti memerlukan adanya aspek sumber daya yang akan menjalankan usaha atau ide menjadi usaha. Dalam beberapa perencanaan sumber daya manusia, perlu menganalisis hal-hal berikut: Mendapatkan sumber daya manusia, Pengembangan sumber daya manusia, Mempertahankan sumber daya manusia (Ismail, 2007).

\section{Strategi Pemasaran}

Setelah tercapai setudi kelayakan bisnis, langkah selanjutnya adalah menentukan strategi pemasaran. strategi pemasaran menurut Craven dalam bukunya Purwanto didefinisikan sebagai analisis strategi pengembangan dan pelaksanaan kegiatan dalam strategi penentuan pasar sasaran bagi produk pada tiap unit bisnis, penetapan tujuan pemasaran, dan pengembangan, pelaksanaan, serta pengelolaan strategi program pemasaran, penentuan posisi pasar yang dirancang untuk memenuhi keinginan konsumen pasar sasaran (Purwanto, 2008).

Kotler mendesain strategi pemasaran meliputi konsep STP (Segmentation, Targeting, Positioning). Konsep ini saling terkait satu sama lainnya (Suryana, 2006). Strategi juga didefinisikan sebagai suatu proses penentuan rencana para pemimpin puncak yang berfokus pada tujuan jangka panjang organisasi, disertai penyusunan suatu cara atau upaya bagaimana agar tujuan tersebut dapat dicapai (Umar, 2001). Secara khusus sebagai tindakan yang bersifat incremental (senantiasa meningkat) dan terus-menerus, serta dilakukan berdasarkan sudut pandang tentang apa yang diharapkan oleh para pelanggan di masa depan (JAB, 2016).

Program pemasaran meliputi tindakantindakan pemasaran yang dapat mempengaruhi permintaan terhadap produk, diantaranya dalam hal mengubah harga, memodifikasi kampanye iklan, merancang promosi khusus, menentukan pilihan saluran distribusi, dan sebagainya (Chandra, 2002).

\section{Perumusan Strategi Pemasaran}

Merumuskan strategi pemasaran berarti melaksanakan prosedur tiga langkah secara sistematis, bermula dari strategi segmentasi pasar, strategi penentuan pasar sasaran, dan strategi penentuan posisi pasar. Ketiga strategi tersebut adalah kunci di dalam manajemen pemasaran, di antaranya adalah:

\section{Strategi Segmentasi Pasar}

Segmentasi pasar adalah proses membagi pasar ke dalam kelompok pembeli yang berbedabeda berdasarkan kebutuhan, karakteristik, ataupun, perilaku yang membutuhkan bauran produk dan bauran pemasaran tersendiri. Atau dengan kata lain segmentasi pasar merupakan dasar untuk mengetahui bahwa setiap pasar terdiri atas beberapa segmen yang berbedabeda (Setiadi, 2003). 


\section{Strategi Penentuan Pasar Sasaran.}

Yaitu pemilihan besar atau luasnya segmen sesuai dengan kemampuan suatu perusahaan untuk memasuki segmen tersebut. Sebagian besar perusahaan memasuki sebuah pasar baru dengan melayani satu segmen tunggal, dan jika terbukti berhasil, maka mereka menambah segmen dan kemudian memperluas secara vertikal atau secara horizontal. Dalam menelaah pasar sasaran harus mengevaluasi dengan menelaah tiga faktor (Umar, 2001):

1) Ukuran dan pertumbuhan segmen

2) Kemenarikan struktural segmen

3) Sasaran dan sumber daya

\section{Strategi Penentuan Pasar}

Sasaran penentuan posisi pasar (positioning) adalah strategi untuk merebut posisi dibenak konsumen, sehingga strategi ini menyangkut bagaimana membangun kepercayaan, keyakinan, dan kompetensi bagi pelanggan. Philip Kotler menyatakan bahwa positioning adalah aktifitas mendesain citra dan memposisikan diri di benak konsumen (Kotler, 1995).

\section{Relijiusitas}

Religiusitas adalah sebuah ekspresi spiritual seseorang dalam keterkaitan dengan sistem keyakinan, nilai hukum yang berlaku dan ritual (sandy, 2016). Religiusitas adalah sesuatu yang sangat penting dalam kehidupan manusia. Aktivitas beragama bukan hanya terjadi ketika seseorang melakukan beribadah, tetapi juga ketika melakukan aktifitas lainnya yang didorong dengan kekuatan supranatural. Bukan hanya yang berkaitan dengan aktivitas yang bisa dilihat dan tampak, tapi juga aktivitas yang tidak tampak dan terjadi dalam hati seseorang. Sikap religiusitas merupakan integrasi secara khusus antara pengetahuan agama, perasaan serta tindakan keagamaan dalam setiap manusia. Religiusitas dapat dilihat dari aktivitas beragama dalam kehidupan sehari-hari yang dilaksanakan secara rutin dan konsisten yang harus dilakukan (Dwiwiyati, dkk., 2011).

\section{Ciri-ciri Religiusitas}

Seseorang dapat dikatakan memiliki religiusitas jika memiliki ciri-ciri berikut (Jalaluddin, 2005) yaitu:

1) Menerima kebenaran agama berdasarkan pertimbangan pemikiran yang matang, bukan ikut-ikutan.

2) Cenderung bersifat realis, sehingga normanorma agama lebih banyak diaplikasikan dalam perilaku dan tingkah laku.

3) Berperilaku positif terhadap ajaran dan norma-norma agama dan berusaha untuk mempelajari dan mendalami pemahaman keagamaan.

4) Tingkat ketaatan beragama didasarkan atas pertimbangan tanggung jawab diri hingga sikap religiusitas merupakan realisasi dari sikap hidup.

5) Bersikap lebih terbuka dan wawasan lebih luas.

6) Bersikap lebih kritis terhadap materi ajaran agama sehingga kemantapan beragama selain didasarkan atas pertimbangan pikiran, juga didasarkan atas pertimbangan hati nurani.

7) Sikap keberagamaan cenderung mengarah kepada tipe-tipe kepribadian masingmasing, sehingga terlihat adanya pengaruh kepribadian dalam menerima, memahami serta melaksanakan ajaran agama yang diyakininya.

8) Terlihat adanya hubungan antara sikap religiusitas dengan kehidupan sosial, sehingga perhatian terhadap kepentingan organisasi sosial sudah berkembang.

\section{Dimensi Religiusitas}

Terdapat lima dimensi keberagamaan, yaitu dimensi keyakinan (ideologis), peribadatan atau praktek agama (ritualistic), penghayatan (experiensial), pengamalan (konsekuensial), pengetahuan agama (intelektual). lima dimensi tersebut menurut Jalaluddin Ancok (2001) adalah:

\section{Dimensi Aqidah Islam}

Menunjuk pada seberapa tingkat keyakinan muslim terhadap kebenaran ajaranajaran agama Islam. Menyangkut keyakinan 
tentang Allah, para malaikat, Nabi dan Rasul, Kitab-kitab Allah, Surga dan Neraka, Qadha dan qadhar (Dwiwiyati, 2011).

\section{Dimensi peribadatan (praktek agama)}

Menunjuk pada seberapa tingkat kepatuhan Muslim dalam mengerjakan kegiatan-kegiatan ritual sebagaimana yang dianjurkan dalam ajaran agama Islam. Menyangkut pelaksanaan shalat, puasa, zakat, haji, membaca Al-Qur'an, doa dan dzikir, ibadah qurban, iktikaf di masjid pada bulan puasa, dan lain sebainya (Dwiwiyati, 2011).

\section{Dimensi akhlak (pengamalan)}

Dimensi ini berkaitan dengan pengalaman keagamaan, perasaan-perasaan, persepsipersepsi, dan sensasi-sensasi yang dialami seseorang akan didefinisikan oleh suatu kelompok keagamaan yang melihat komunikasi, walaupun kecil, dalam suatu esensi ketuhanan, yaitu dengan Tuhan, kenyataan terakhir, dengan otoritas transedental (fauzan, 2013).

\section{Dimensi Ilmu (pengetahuan).}

Menunjuk pada seberapa tingkat pengetahuan dan pemahaman Muslim terhadap ajaran agamanya. Menyangkut pengetahuan tentang isi Al-Qur'an, pokok-pokok ajaran yang harus diimani dan dilaksanakan (rukun Islam dan rukun Iman), hukum-hukum Islam, sejarah Islam, dan lain sebagainya (Edy, 2012).

\section{Dimensi Penghayatan.}

Menyangkut tentang perasaan dekat dengan Allah, perasaan doanya sering terkabul, perasaan tentram dan bahagia karena Allah, perasaan bertawakal kepada Allah, perasaan khusuk ketika melaksanakan shalat, perasaan bergetar mendengar adzan dan ayat Al-Qur'an, perasaan bersyukur kepada Allah, perasaan mendapat peringatan dan pertolongan dari Allah SWT (Dian, 2016).

\section{METODE PENELITIAN}

Rancangan penelitian adalah rencana dan struktur investigasi yang dibuat sedemikian rupa sehingga diperoleh jawaban atas pertanyaan riset (Schindler, 2006). Penelitian ini termasuk dalam penelitian kausal dimana peneliti ingin menemukan penyebab dari satu atau lebih masalah (Bougie dan sakaran, 2010). Dalam sumber data yang digunakan pada penelitian ini menggunakan sumber data primer, dimana mengacu pada informasi yang diperoleh dari tangan pertama (responden) oleh peneliti dan pengumpulan data yang dilakukan yaitu melalui survey dengan mengajukan pertanyaan kepada Profil Pemasaran Waroeng Spesial Sambal. Yang dipertanyakan terkait dengan; Strategi Pemasaran, Produk, Harga, Distribusi, Promosi, Segmentasi, Target Pasar, Lokasi.

Jenis penelitian ini adalah penelitian kualitatif dengan menggunakan pendekatan lapangan (field research), dimana peneliti mengumpulkan data secara langsung dating ke lokasi peneltian, dengan melakukan observasi, wawancara dan dokumentasi.

Obyek penelitian adalah Waroeng Spesial Sambal (atau dikenal Waroeng SS), berlokasi di Jln. Kaliurang Km 4.5, Gg. Kinanti No.19 Mlati Sleman, Yogyakarta.

Data primer diperoleh dari hasil wawancara peneliti dengan pihak Waroeng SS yang diwakili bapak Widyatmoyo (Kepala Humas dan CSR Waroeng SS, Yogyakarta). Di samping itu juga wawancara kepada konsumen sebagai bukti kepuasan pelayanan yang diberikan oleh pihak perusahaan Waroeng SS. Adapun jenis wawancara yang digunakan peneliti adalah wawancara tersetruktur sehingga memperoleh jawaban sperti apa yang diinginkan peneliti. Adapun variabel yang diteliti adalah; studi kelayakan usaha dan strategi pemasaran Waroeng SS.

\section{HASIL DAN PEMBAHASAN}

Berdasarkan analisis di atas menggunakan hasil observasi, wawancara, dan kuesioner maka dapat diketahui hasil analisis sebagai berikut:

\section{Profil Usaha Waroeng Spesial Sambal}

Waroeng Spesial Sambal atau dikenal masyarakat dengan "SS" dibuka tepat tanggal 20 Agustus 2002. Waroeng "SS" didirikan oleh bapak Yoyok Hery Wahyono alumni teknik kimia UGM. Dengan modal awal Rp. 9.000.000,- dan jumlah karyawan 4 orang, 
didirikanlah Waroeng "SS" pertama kali disebelah barat Grha Sabha Pramana (GSP) dengan bentuk hanya warung kaki lima dan kini diberi nama waroeng "SS" Perjuangan. Alasan bapak Yoyok Hery Wahyono memilih membuka warung ini karena kegemaran beliau terhadap dunia masak terutama sambal. Dan karena kesukaannya terhadap kuliner sambal, bapak Yoyok Hery Wahyono sejauh ini telah mencetuskan 27 macam sambal dan memberi nama warungnya "Waroeng Spesial Sambal".Pemilihan lokasi awal/pertama kali waroeng "SS" didirikan adalah disebelah barat GSP karena paling dekat dengan kontrakan bapak Yoyok semasa kuliah dulu (www. spesialsambel.com).

Warung yang beliau rintis secara terus-menerus berkembang sampai menjadi besar. Untuk memenuhi kebutuhan hidup di Yogyakarta, beliau membuka Waroeng SS ke dua (2) di Condong Catur. Selanjutnya ditambah waroeng SS ke tiga (3) di Seturan arah ke Babarsari. Berikutnya menyusul yang ke empat (4) di Pandega Marta, terus yang ke lima (5) di Jalan Kaliurang km. 14. Selanjutnya selama kurang lebih 1,5 tahun keinginan untuk mendirikan Waroeng SS ke enam (6) namun tidak tersampaikan. Dan akhirnya berdiri yang ke-7 di Timoho dalam 2 bulan kemudian berdiri, menyusul yang ke-8 di Glagahsari jalan juga (bisnisukm.com), ditawarkan ada 28 varian sambal dengan nama unik namun rasa khas Jawa Tengah. Hingga saat ini beliau memiliki Waroeng Spesial Sambal (SS) yang telah memiliki 80 outlet di 45 kota (Jawa-Bali) dengan 3.600 orang pegawai (wawancara bpk. Wahyono).

Berbasiskan hobi dan kegemaran bapak Yoyok Hery Wahyono tersebut di atas, beliau berencana memenuhi kebutuhan hidup di kota Yogyakarta bersama temen-temennya (5 orang), juga melibatkan personil-personil InSEd yang perannya tidak bisa dilepaskan dari sejarah Waroeng SS. Rahasia Kesuksesan Waroeng Spesial Sambal (SS) adalah selalu bersyukur dan berbagi. Ria (Pihak Kru SS) mengungkapkan jika banyak program sosial yang dilakukan manajemen, antara lain beasiswa untuk anak karyawan, beasiswa untuk karyawan hingga magister manajemen, dana sosial, dana pensiun, BPJS, dan satu persen dari omzet untuk sodaqoh dan infaq.
Dalam memenuhi kebutuhan bahan baku yang ada, Waroeng SS juga memberdayakan pesantren, perkumpulan para ibu-ibu pkk, dan warga daerah-daerah yang menyanggupi untuk memasok barang yang tidak tetap pemasokannya. Tetapi bagi para pemasok tetap, akan tetap memasok bahan baku yang kuantitasnya selalu banyak untuk setiap harinya, demi memenuhi kebutuhan Waroeng SS setiap hari ke dapur pusat dan akan didistribusikan ke warung-warung cabang.

\section{Analisis Kelayakan Bisnis}

Bapak Yoyok Hery W selaku owner Waroeng SS menganlisis aspek-aspek kelayakan bisnis yang penting berikut:

\section{Aspek Pemasaran}

Motivasi

Sebagaimana telah disebutkan diatas bahwa bapak Yoyok Hery W. (owner perusahaan) memiliki motivasi untuk bertahan hidup dan memperbaiki keadaan ekonomi keluarga. Di mana pemilik adalah anak sulung yang sekolah di Perguruan Tinggi jurusan Teknik Kimia, yang masih harus membantu sang ibu dalam biaya sekolah adiknya, sang ibu hanya seorang guru, sedangkan ayah beliau sudah meninggal. Sehingga motivasi usaha muncul pada diri beliau dan menumbuhkan mental seorang entrepreneur.

\section{Metode Pemasaran}

Metode pemasaran yang dilakukan oleh owner Waroeng SS adalah fokus memuaskan pelanggan. Sampai saat ini-pun usaha kuliner tersebut tetap mengutamakan pelayanan yang memuaskan konsumennya, karena owner memiliki slogan "pembeli adalah raja". Maka cita rasa, kebersihan, kecepatan dan semuanya disiapkan dan disajikan layaknya persembahan untuk raja.

\section{Strategi Pemasaran}

Strategi pemasaran yang dimiliki oleh owner berdasarkan marketing mix, adalah berikut:

\section{Produk}

Produk utama dari Waroeng SS adalah "sambal", dari awal berdirinya hingga sekarang. Karena sambal merupakan ciri khas 
makanan orang Indonesia. Bapak Widyatmoyo ${ }^{2}$ menyatakan: "Bagi orang Indonesia, Sambal itu layaknya garnish pada makanan, yang bisa membuat para penggemarnya kecanduan akan sensasi pedasnya, yang semakin lama penggemarnya selalu bertambah"

\section{Harga}

Konsumen yang dijadikan sasaran utama perusahaan Waroeng SS adalah mahasiswa yang dari dulu hingga sekarang terdiri dari berbagai masyarakat ekonomi (bawah hingga atas). Dengan demikian perusahaan mematok harga yang terjangkau bagi semua lini ekonomi mahasiswa, namun tetap menjaga kualitas produk yang baik dan memuaskan (wawancara Bpk. Widyatmoyo).

\section{Promosi}

Sejak awal usaha Waroeng SS, strategi promosi yang dilakukan perusahaan adalah "dari mulut ke mulut", yang artinya tidak pernah ada promosi berbentuk iklan yang dipublikasikan baik bentuk brosur maupun media lainnya. Semua berbasis pada kepercayaan konsumen kepada usaha Waroeng SS; awalnya dulu dari beberapa orang teman sekampus bapak Yoyok Hery W. berlanjut pada ratusan konsumen per harinya saat ini (wawancara Bpk. Widyatmoyo).

\section{Tempat}

Berawal dari warung tenda yang berlokasi di sekitar gedung auditorium Graha Sabha Pranama UGM. Lokasi ini menjadi pilihan bapak Yoyok hery W. karena sasaran konsumennya adalah para mahasiswa, khususnya temanteman beliau saat itu. Selanjutnya sasaran kedua adalah mahasiswa kampus Condong Catur, sehingga cabang pertama Waroeng SS dibangun di Condong Catur Sleman Yogyakarta, dan kini dikenal diberbagai daerah sehingga jumlah outlet (warung) saat ini mencapai 80 cabang di seluruh Jawa-Bali.

Dan hampir semua lokasi di 80 cabang itu adalah sewa, tetapi hanya outlet (warung) saja yang menyewa, untuk setiap daerahnya terdapat kantor manajemennya, sudah tanah

\footnotetext{
${ }^{2}$ Bapak Widyatmoyo, Kepala Humas dan CSR Waroeng Spesial Sambal, Yogyakarta.
}

milik sendiri. Untuk lokasi outlet (warung), investor menginvetasikan lokasinya pada perusahaan sekitar 600 Juta hingga 1 Miliyar Rupiah per lokasi.

\section{Bukti Nyata (Nilai Plus)}

Dari awal berdirinya, Waroeng SS ini sudah memiliki nama usaha (merk) atau brand, yang mana pada waktu itu masih jarang warung makan memiliki nama (merk). Misi dan visi perusahaan ini, selain untuk mencari keuntungan juga memperkuat brand atau merk. Selain itu, dengan menyediakan berbagai macam lauk-pauk dan beraneka ragam sambal, dimana usaha ini memberikan kebijakan bagi yang ingin menambah nasi tidak dipungut suatu biaya apapun (wawancara Bpk. Widyatmoyo).

\section{Aspek Industri}

Proses Manajemen Resiko

Kebijakan Pemerintah

Kebijakan pemerintah atau biasa disebut dengan pajak, Waroeng Spesial Sambal selalu mentaati peraturan yang dibebankan kepada seluruh warga negara Indonesia. Yang terdiri dari beberapa jenis kewajiban pajak yang dibebankan kepada Waroeng SS ialah, PPN, $\mathrm{PBB}$, dan PPh.

\section{Pesaing}

Dalam menghadapi para pesaing yang semakin banyak, dengan desain warung, produk, dan lain sebagainya. Waroeng SS tetap menjaga eksistensinya, dan tetap menjaga semua aspek yang sudah sejak awal berdirinya sudah ada, seperti selalu menjaga kualitas sambal yang diproduksinya, dan selalu meningkatkan pelayanan yang berkualitas kepada kosumen.

\section{Ancaman Produk Pengganti}

Dewasa ini, diakui oleh pihak owner banyak warung-warung makan (restoran) yang dibuka oleh warga asing yang sama-sama bersaing dalam produk yang sama dan serupa dengan Waroeng SS, untuk menyikapinya masalah tersebut Waroeng SS tetap teguh (istiqomah) dalam semua bentuk komitmen pelayanan dan produk yang dimiliki sejak awal berdirinya. 
Kerjasama

Waroeng SS memiliki mitra yang bisa dikatakan cukup banyak, terutama dalam hal pasokan (supplier) bahan baku. Bahan baku yang diperlukan untuk dapur pusat bisa mencapai 200 item, dengan setiap itemnya mencapai 3 hingga 4 supplier. Supplier bahan baku terdiri dari lembaga swasta seperti pesantren, ibu-ibu PKK, dll. dan supplier sosial; seperti lembaga sosial kemasyarakatan (wawancara Bpk. Widyatmoyo).

\section{Aspek Produksi atau Operasional}

Berdasrakan wawancara peneliti dengan bapak Widyatmoyo sebagai Kepala Humas dan CSR Waroeng SS, Yogyakarta, didapatkan hasil sebagai berikut:

\section{Sasaran Pasaran}

Dulu sasaran utama pangsa pasar perusahaan adalah masyarakat mahasiswa, namun sekarang sudah mencakup semua kalangan masyarakat.

\section{Harga Pasaran}

Karena alasan kecerdasan para konsumen (mahasiswa) dan daya analisisnya terkait dengan suatu produk yang mereka konsumsi, maka Waroeng SS senantiasa menampung kritik dan memberikan solusi atas masukan mereka. Waroeng SS tetap memberikan harga yang terjangkau (bagi mahasiswa) dan disertai dengan pelayanan yang baik.

\section{Kemajuan Teknologi}

Waroeng SS tidak melakukan kerjasama dengan lembaga yang memainkan finance technology, Waroeng SS lebih memilih untuk melakukan semua kegiatan produksi dan konsumsi secara langsung, walau sudah banyak lembaga yang menawarkan bekerjasama dengan pihak Waroeng SS.

\section{Desain/ layout Lokasi Penjualan (Outlet)}

Diawal berdirinya, Waroeng SS menggunakan desain warung yang tidak dimiliki atau digunakan oleh warung lainnya (saat itu), di depan diletakan beberapa pot-pot bunga (hiasan sekitaran warung), dan di dalam warung dipajang beberapa kata-kata mutiara yang ditempelkan di dinding.
Desain yang digunakan Waroeng SS ialah lebih ke bangunan rumah layaknya rumah umumnya, ada teras, ruang tengah, dan ruang dalam. Dengan tujuan, agar para konsumen yang makan di Waroeng SS merasakan sensasi makan layaknya di rumah sendiri.

\section{Kerja Operasional}

Sistem yang dijalankan oleh manajemen Waroeng SS sama seperti perusahan lainnya; terdapat direktur, manajer, dan anggota. Semua sesuai dengan bidangnya masingmasing, dan selalu mengadakan evaluasi untuk seluruh mitra setiap 3 bulan sekali.

\section{Aspek Keuangan \\ Modal}

Modal yang dikeluarkan untuk membangun usaha Waroeng SS seluruhnya dana dari owner (Bapak Yoyok Hery W.). Dan model usaha ialah owner (dimiliki sendiri).

\section{Sikap Kenaikan Harga Bahan Baku}

Cabe adalah bahan baku utama perusahaan Waroeng SS dan grafik harga cabe sesuai periode-nya. Menyiasati hal tersebut, Waroeng SS sudah memiliki supplier tetap dan harganya berbeda dengan pasaran, tetapi adakalanya walau harga cabe saat itu sedang melambung Waroeng SS tetap membelinya. Karena Waroeng SS sangat mengedepankan kepuasan konsumennya daripada keuntungan yang akan diperoleh, dengan kepercayaan kepada-Nya.

Justru disaat harga cabe naik, jumlah konsumen yang ada malah bertambah dari biasanya, "Itulah Rahmat dari Allah, walau kami mendapatkan harga bahan baku yang naik, tapi tetap tidak mengurangi kuantitas dan tingkat kepedasan sambal, malah bertambah konsumen dari biasanya" (wawancara Bpk. Widyatmoyo).

\section{Pendapatan}

Pendapatan (omset) yang didapat oleh Waroeng SS tidaklah tentu, rata-rata omset yang didapat untuk keseluruhan dari 80 outlet di Jawa-Bali hampir mencapai 1 Miliyar Rupiah per-bulannya. Dan alokasi pendapatan yang didapat dari keseluruhan omset, akan digambarkan dengan diagram sebagai berikut: 


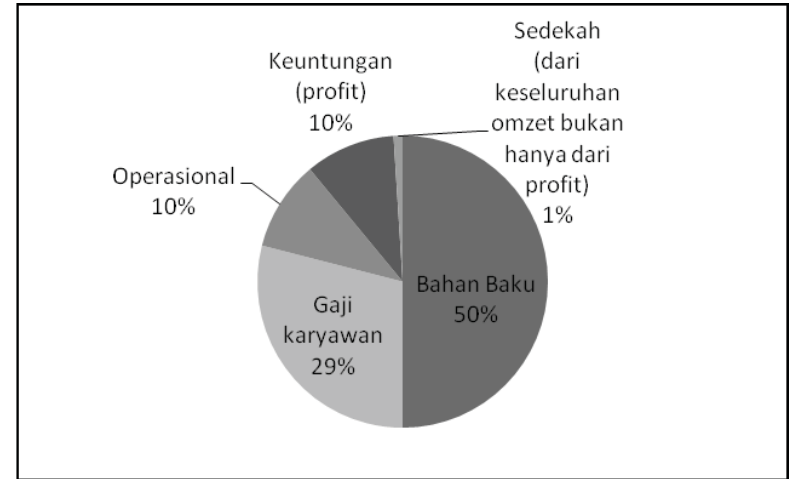

Gambar 1. Alokasi Pendapat Waroeng SS

Keterangan:

1. Dari Pendapatan kotor yang dialokasikan ke bahan baku atau modal Waroeng SS sebesar 50\% dan bersifat konstan.

2. Dari Pendapatan kotor yang dialokasikan ke gaji karyawan Waroeng SS sebesar $29 \%$.

3. Dari Pendapatan kotor yang dialokasikan ke biaya operasional seperti; biaya listrik, biaya air, dan lain-lain Waroeng SS sebesar $10 \%$.

4. Dari pendapatan kotor, keuntungan (profit) bersih yang didapat Waroeng SS sebesar 10\%.

Dari keseluruhan pendapatan kotor (belum dikurangi pengeluaran apapun) sebesar $1 \%$ dialokokasikan untuk sedekah, yang diberikan kepada orang-orang dan lembaga-lembaga yang membutuhkan.

\section{Aspek Sumber Daya Manusia}

Karyawan

Pengangkatan Karyawan

Hingga saat ini Waroeng SS telah memiliki kurang lebih 3.600 orang karyawan, yang terdiri dari; 400 orang karyawan yang bekerja di manajemen operasional, dan 3.200 orang karyawan bekerja langsung di 80 outlet se-Jawa dan Bali. Sistem penugasannya pun sesuai dengan latar belakang pendidikan setiap karyawan.

\section{Persyaratan Karyawan}

Untuk karyawan yang bekerja di manajemen operasional (kantor), disesuaikan dengan bidang yang melatar belakangi pendidikannya, minimal pendidikan akhirnya adalah Strata satu (S1) atau Diploma (D3). Sedangkan untuk karyawan yang bekerja di outlet atau warung terdiri dari dua jenis pekerjaan. Pertama; karyawan yang menjadi pramuniaga minimal memiliki pendidikan terakhir Sekolah Menengah Atas (SMA); Kedua; karyawan yang melayani konsumen bagian kasir minimal memiliki pendidikan akhir Sekolah Menengah Kejuruan (SMK) yang sudah berbekal ilmu ekonomi atau akuntansi. Dan karyawan khusus dan memiliki peran yang sangat penting ialah koki masak, minimal memiliki pendidikan akhir Sekolah Menengah Kejuruan (SMK) tataboga, dan memiliki sertifikasi kejuruan memasak.

\section{Penghargaan Terhadap Karyawan}

Setiap bulan akan memberikan penghargaan atau yang disebut juga bonus kerja kepada siapa saja karyawan yang memiliki kinerja yang baik selama bekerja diluar gaji pokok yang mereka terima.

\section{Konsumen}

\section{Pelayanan yang diberikan kepada konsumen}

Jika ada konsumen yang merasa pelayanan Waroeng SS kurang memuaskan, Waroeng SS selalu menyediakan dan mengharapkan kritik serta saran yang membangun guna tercapainya kenyamanan konsumen Waroeng SS berikutnya. Dan jika ditemukan karyawan Waroeng SS yang tidak memuaskan konsumen, maka akan ditegur pihak pengelola Waroeng SS (wawancara Bpk. Widyatmoyo).

\section{Pelayanan Waroeng SS menurut konsumen}

Hasil wawancara antara peneliti dan konsumen terkait pelayanan Waroeng SS, adalah sebagai berikut:

\section{Tabel 1. Hasil Wawancara Waroeng SS}

\begin{tabular}{lrr}
\hline \multicolumn{1}{c}{ Aspek } & Positif & Negatif \\
\hline Pemasaran & $80 \%$ & $20 \%$ \\
Sumber Daya Manusia & $70 \%$ & $30 \%$ \\
Operasional & $90 \%$ & $10 \%$ \\
\hline
\end{tabular}

Keterangan:

a. Aspek pemasaran yang mencakup; varian menu dan lokasi warung.

b. Aspek SDM yang mencakup; kuantitas pelayan.

c. Aspek operasional yang mencakup; harga produk dan kualitas pelayanan.

\section{Cara mempertahankan konsumen}

Waroeng SS selalu memberikan pelayanan terbaik dan kualitas produk makanan (khususnya sambal) yang terjaga, biasanya untuk setiap jenis sambal memiliki jangka waktu dalam penyajiannya. Inilah yang membuat cita rasa sambal yang segar, dan kemudian akan disajikan kepada para konsumen. 


\section{Aspek Relijiusitas}

Pada aspek relijiusitas ini Bapak Yoyok Hery Wahyono mencoba untuk terus meyakini kalo angka-angka rejeki itu memang urusan Allah Yang Maha Kuasa \& Maha Adil, sedangkan manusia hanyalah bertugas mengerjakan apa yang didepan kita dengan sebaik-baiknya yang mereka bisa. Sehingga bpk heri wahyono berkomitmen bahwa dari keseluruhan pendapatan kotor (belum dikurangi pengeluaran apapun) sebesar 1\% dialokokasikan untuk sedekah, yang diberikan kepada orang-orang dan lembaga-lembaga yang membutuhkan.

Bentuk ikhtiyar owner terhadap kesuksesan bisnis kuliner ini adalah mencoba memberikan pelayanan yang cepat dan memuaskan kepada konsumen, aneka menu sambal yang tidak pernah kurang dari standar pedasnya meskipun saat itu harga cabai sedang naik, disamping harga setiap menu terjangkau bagi konsumen. Banyak ikhtiyar-iktiyar yang dilakukan oleh pihak owner untuk mengais rezeki halal, sehingga sering ada inovasi baru pada produknya.

\section{KESIMPULAN}

Analisis kelayakan bisnis pada unit usaha kuliner Waroeng SS pertama tidak melepaskan keyakinan bahwa rezeki telah diatur Allah Swt, dan selanjutnya dilakukan ikhtiyar (motivasi kuat) terhadap masalah pasar. Diketahui bahwa pasar saat itu adalah mahasiswa, di mana pada umumnya mahasiswa notabene memenuhi kebutuhan makan setiap harinya dengan datang ke warung makan namun dengan harga yang terjangkau. Selanjutnya dilakukan analisa bahan baku guna mempertahankan kulitas produk; dengan teknik penjadwalan terkait pengadaan bahan baku dari supplier. Lalu penyiapan SDM yang kemudian diadakan pembagian jadwal pekerjaan, sehingga tersusun SOP sederhana, disertai pengawasan dan pengendalian mutu produk. Pembuatan sambal khas Waroeng SS diadakan pelatihan SDM secara berkala supaya tetap terjaga kualitasnya. Selanjutnya bila permintaan pasar masih banyak maka dengan dasar analisa di atas perlu diadakan penambahan outlet.

\section{DAFTAR PUSTAKA}

Chandra, Gregorius, 2002, Strategi dan Program Pemasaran, Penerbit Andi Ofset, Yogyakarta

Dewi Purnamasari dan Bambang hendrawan, 2008, Analisis Kelayakan Biasnis Usaha Roti Ceriwis sebagai Oleh-oleh Khas Kota Batam

Dian Kusumaningsih, 2016, "Religiusitas Pada Motivasi Dan Etika Profesi Akuntan Dalam Prespektif Islam", Jurnal Akuntansi, (Volume 4, No. 3, September)

Djamaludin Ancok dan Suroso F., 2001, Psikologi Islami, Solusi Islam Atas Problem-Problem Psikologi. (Yogyakarta: Pustaka Pelajar)

Donald R. Cooper and Pamela S, Schindler, 2006, Metode Riset Bisnis, PT. Media Global Edukasi, Jakarta.

Dwiwiyati Astogini, Wahyudin, danSiti Zulaikha Wulandari, 2011, "Aspek Religiusitas Dalam Keputusan Pembelian Produk Halal", Jurnal Ekonomi Bisnis dan Akuntansi, (Vol. 13, No. 1, Maret 2011)

Edy Chandra, 2002, "Religiusitas Dalam Pendidikan Kimia (Esensi Pemikiran Pendidikan Kimiawan Klasik Jabir Bin Hayyan)", Jurnal Scientiae Educatia, (Volume 1, edisi 1, April)

Fahrizal dkk, Suistanable Forest Management Analysis on Conventional Silviculture and Intensive Silviculture System: A Case Study at PT. Suka Jaya Makmur, West Kalimantan, Bogor: Institut Pertanian Bogor

Fandy Tjiptono dan Gregorius Chandra, 2012, Pemasaran Strategik, ed. 2, CV. Andi Offset, Yogyakarta.

Fauzan, 2013, “Pengaruh Religiusitas Terhadap Etika Berbisnis", Jurnal Managemen dan Kewirausahaan, (Volume.15, No. 1, Maret)

Ibrahim, Yacob, 2003, Studi Kelayakan Bisnis, PT Asdi Mahasatya, Jakarta.

Idrus, Muhammad, 2002, Kecerdasan Spiritual Mahasiswa Yogyakarta, Artikel tidak diterbitkan

Irawan, Faried, Wijaya dan M.N. Sudjoni, 1998, Pemasaran Prinsip dan Kasus, Edisi 2, BPFE Yogyakarta, Yogyakarta.

Jalaluddin, 2005, "Psikologi Agama", (Jakarta: PT. Grafindo Persada, 2005)

Jurnal Administrasi Bisnis (JAB) | Vol. 29 No.1 Desember 2015. 
Jurnal Akuntansi, Ekonomi dan Manajemen Bisnis | 2013 Vol. 1(1) 83-87 | ISSN: 23377887.

Jurnal Jurusan Ekonomi Manajemen, Fakultas Ekonomi, Universitas Gunadarama. 3

Jurnal PASTI Volume VIII No 1, 122 - 141.

Kasmir dan Jakfar, 2007, Studi Kelayakan Bisnis (Edisi Refisi), Pranada Media Group, Cet Ke-10.

Kasmir dan Jakfar, 2007, Studi Kelayakan Bisnis, Edisi Kedua, Cetakan Keempat, Prenada Media Group, Jakarta.

Kotler, Philip, 1995, Manajemen Pemasaran: Analisis, Perencanaan, Implementasi dan Pengendalian, Edisi Indonesia, Salemba Empat, Jakarta.

Lisda Rahmasari, 2012, Pengaruh Kecerdasan Intelektual, Kecerdasan Emosi dan Kecerdasan Spiritual Terhadap Kinerja Karyawan, Majalah Ilmiah INFORMATiKA Vol.3 No. 1, Januari 2012, Fakultas Ekonomi Universitas AKI,

Nunung Nurhayati, Musa Hubeis dan Sabta Raharja, 2009, Kelayakan dan Strategi Pengembangan Usaha Industri Kecil Tahu Di Kabupaten Kuningan, Jawa Barat, Jurnal Manajemen IKM, September 2009 (225-235) Vol. 4 No. 2 ISSN 2085-8418.

Purwanto, Iwan, 2008, Manajemen Strategi, Yrama Widya, Bandung.

Rambat Lupiyoadi dan A. Hamdani, 2006, Manajemen Pemasaran Jasa, Salemba Empat, Jakarta.

Roni Mohammad dan Mustofa, "Pengaruh Tngkat Pemahaman Agama Terhadap Pelaku Bisnis Pedagang Pasar Minggu Telaga Kabupaten Gorontalo. Jurnal AlMizan, (Vol 10 Nomor 1, Juni 2014), hal 1-16.

Rusdiana, 2014, Kewirausahaan Teori dan Praktik, CV Pustaka Setia, Bandung.
Sandy Hendra Mukti, Juiani Pudjowati, Anggraeni Rahmasari, 2016, "Pengaruh Religiusitas, motif ekonomi dan sikap istiqomah terhadap perilaku nasabah dalam menabung pada Bank Muamalat Mojokerto", Jurnal Ekonomi Pembangunan (Volume 2, Issue 1 2016)

Setiadi, Nugroho J, 2003, Perilaku Konsumen: Konsep dan Implikasi untuk Strategi dan Penelitian Pemasaran, Kencana, Jakarta.

Sidik Ignas G, 2013, Bisnis sukses: menyusun Rencana Lengkap Terpadu, Gramedia pustaka utama, Jakarta.

Solihin, Ismail, 2007, Memahami Business Plan, Salemba Empat, Jakarta.

Sudaryono, 2015, Pengantar Bisnis Teori \& Contoh Kasus, C.V ANDI OFSET, Yogyakarta.

Suharsimi Arikunto, 2006, Prosedur Penelitian Suatu Pendekatan Praktek, Rineka Cipta, Jakarta.

Suryana, 2006, Kewirausahaan, Salemba Empat, Jakarta.

Teknik Industri Itenas | No.3 | Vol.1 Jurnal Online Institut Teknologi Nasional [Desember, 2013] ISSN: 2338-5081.

Uma Sekaran dan Roger Bougie, 2010, Research Methods for Bussinnes: a skill building approach, Fifthi edition, (West Sussex: John Wiley, and Sons, Ltd.)

Umar, 2001, Strategic Management in Action, Konsep, Teori, dan Teknik Menganalisis Manajemen Strategis Strategic Business Unit Berdasarkan Konsep Michael R. Porter, Fred R. David, dan Wheelan- Hunger. PT Gramedia Pustaka Utama, Jakarta.

Umar, Husein, 2007, Studi Kelayakan Bisnis, PT Gramedia Pustaka Utama, Jakarta.

Wikipedia bahasa Indonesia, ensiklopedia bebas, Yoyok Hery Wahyono 